\title{
Simultaneous measurement of phytoplanktonic primary production, nutrient and light availability along a turbid, eutrophic UK east coast estuary (the Colne Estuary)
}

\author{
Esra Kocum*, Graham J. C. Underwood**, David B. Nedwell \\ Department of Biology, University of Essex, John Tabor Buildings, Wivenhoe Park, Colchester CO4 3SQ, United Kingdom
}

\begin{abstract}
Primary production, algal biomass, light conditions and dissolved inorganic nutrient concentrations were monitored simultaneously along the Colne Estuary, UK for a period of 15 mo. Phytoplanktonic primary production and chlorophyll a (chl a) concentration ranged from $0.64 \times 10^{-3}$

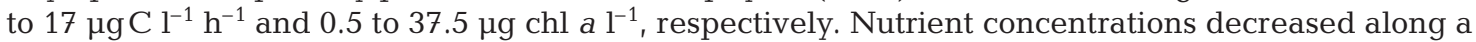
downstream gradient, with high concentrations of nitrate $(564 \mu \mathrm{M})$, ammonium $(291 \mu \mathrm{M})$ and phosphate $(52 \mu \mathrm{M})$ present at the head of the estuary. Despite high light-attenuation coefficients (mean $K=3.2 \mathrm{~m}^{-1}$ ), the greatest phytoplankton biomass and primary production were measured at the head of the estuary, where nutrient concentrations were high, and phytoplankton biomass and primary production decreased down the estuarine gradient. Despite year-round high nutrient concentrations, chlorophyll a concentrations and rates of primary production remained below levels reported for bloom formation in similar systems. Comparison of field data with measurements derived from phytoplanktonic $P$ vs $E$ curves showed that simulated in situ rates of surface-water biomass-normalised production $\left(P^{\mathrm{B}}\right)$ were usually significantly lower than the $P_{\max }^{\mathrm{B}}$ values of the phytoplankton. Therefore phytoplankton primary production in the Colne Estuary was light-limited for most of the year, and increased algal biomass and production towards the head of the estuary (despite high attenuation coefficients) was due to a shallow, well-mixed water column (low $Z_{\text {mix }}: Z_{\text {eu }}$ [critical mixing ratio]).
\end{abstract}

KEY WORDS: Phytoplankton $\cdot$ Estuary $\cdot$ Primary production $\cdot$ Chlorophyll $a \cdot$ Light-limitation

\section{INTRODUCTION}

Estuaries are characterised by strong gradients in river flow, circulation, tidal mixing, nutrient inputs, sediment loading and temperature. The interplay of these properties produces spatially and temporally heterogenous conditions for phytoplankton (Lawrence \& Harding 1994). These heterogenous conditions cause seasonal and spatial variation in the estuarine environment, and in biological processes such as phytoplankton growth and primary production and in

\footnotetext{
${ }^{*}$ Present address: Canakkale Onsekiz Mart University, Fen-Ed. Fak., 17100 Canakkale, Turkey

${ }^{* *}$ Corresponding author. E-mail: gjcu@essex.ac.uk
}

the factors controlling these biological processes (Pennock \& Sharp 1994). Estuaries are among the most productive environments and their importance in terms of carbon fixation, fisheries habitat, nutrient assimilation, water storage and sediment stabilisation has long been recognised (Baban 1997). A few studies of estuaries provide a simultaneous examination of temporal and spatial variability in phytoplankton production and factors causing this variability (Pennock \& Sharp 1986, Cloern 1996, Malone et al. 1996, Kinney \& Roman 1998). However, relatively little information is available on the spatial and temporal variability of estuarine phytoplankton, especially in the turbid European estuaries (Cadee \& Hegeman 1974, Kromkamp \& Peene 1995). 


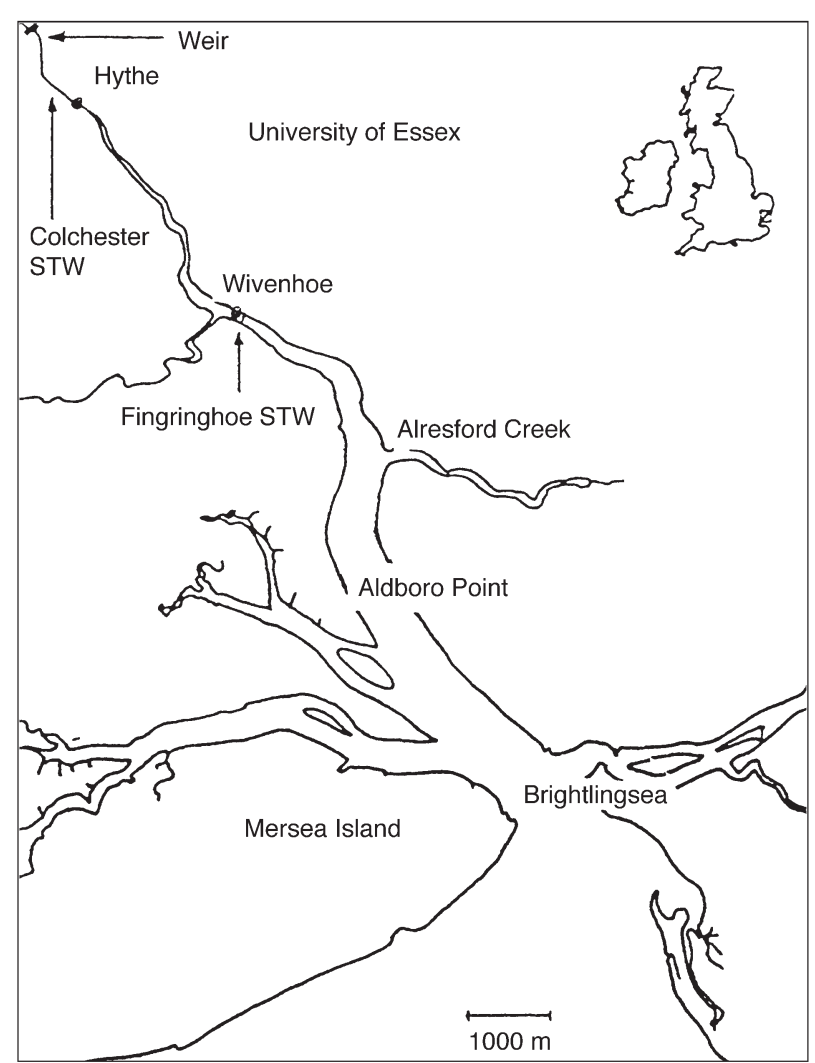

Fig. 1. Map of the Colne Estuary showing locations of the sampling sites. STW: domestic sewage treatment works

Estuarine phytoplankton production is often considered to be regulated by either light or nutrients, although the two may interact (MacIsaac \& Dugdale 1972, Underwood \& Kromkamp 1999). Light is the major regulator of primary production in turbid estuaries (Cole \& Cloern 1984, 1987, Pennock 1985, Soetart et al. 1994, Kromkamp \& Peene 1995). Although nitrogen is usually considered to be the nutrient limiting primary production in marine and coastal marine systems (D'Elia et al. 1986, Hecky \& Kilham 1988), the evidence for this is not as strong as the evidence that freshwaters tend to be P-limited. The situation regarding $\mathrm{N}$ and $\mathrm{P}$ is even more uncertain for estuaries, as the interplay of heterogenous conditions causes spatial and seasonal variation in the variables limiting primary production (Malone et al. 1996, Underwood \& Kromkamp 1999). The general seasonal pattern is of light-limitation during winter and N-limitation over summer, while a spatial trend is identified with N-limitation at the seaward end and P-limitation at the freshwater end (D'Elia et al. 1986, Fisher et al. 1992, Pennock \& Sharp 1994, Doering et al. 1995).
This paper presents the results of a study of phytoplankton activity in a hypernutrified estuary, the Colne Estuary, UK, which exhibits a strong gradient of nutrient concentrations from the freshwater to the marine end (Ogilvie et al. 1997). The seasonal and spatial variation in primary production, chlorophyll a ( $\mathrm{chl} \mathrm{a),} \mathrm{dis-}$ solved inorganic nutrients (ammonium, nitrate, phosphate and silicate) and light characteristics (as depth of euphotic zone, $Z_{\text {mix }}: Z_{\text {eu }}$ ratios, depth-integrated average irradiance) were examined, and the data are discussed with regard to light-limitation.

\section{MATERIALS AND METHODS}

Sampling area. The Colne is a shallow, well-mixed (Sage 1995, Ogilvie et al. 1997), macro-tidal (tidal range 3.5 to $4.0 \mathrm{~m}$ ) estuary in SE England, entering the North Sea at Brightlingsea (Fig. 1). The estuary is comparatively short (10 km long), but branching $(90 \mathrm{~km}$ shore-line), with 5 tidal arms running into the main river channel (Fig. 1 and Elliot et al. 1993). The depth of the water column at high tide varies between $14 \mathrm{~m}$ at Brightlingsea, $10 \mathrm{~m}$ at Aldboro Point, $5 \mathrm{~m}$ at Wivenhoe and $3 \mathrm{~m}$ at Hythe. Salinity varies between 0 and 33 along the estuary on high tide. The biological and chemical quality of the water is affected by riverine discharge of nutrients and by discharges from domestic sewage treatment works (STW), resulting in a strong gradient of increasing concentrations of ammonium, nitrate, silicate and phosphate towards the head of the estuary (Ogilvie et al. 1997). STW effluent is the main source of ammonium and phosphate while riverine discharge accounts for most of the total oxidizied nitrogen, TON (= nitrate + nitrite), and silicate (Elliot et al. 1993).

Four sites (Hythe, Wivenhoe, Aldboro Point and Brightlingsea; Fig. 1) were selected to cover the estuarine salinity gradient. Quadruplicate samples of surface water were collected at each site in mid-channel at high tide approximately every month from September 1994 (nutrients from June) to November 1995. Samples were collected over 2 successive days to enable primary production incubations to be commenced within $1 \mathrm{~h}$ of sample collection. On the first day, Brightlingsea and Aldboro Point were sampled from midchannel using an inflatable boat. The narrow nature of the 2 remaining sites (Wivenhoe and Hythe) permitted sampling off the edge of a tidal storm-surge barrier and a quayside, using a rope and bucket. Algal biomass (as chl a concentration) dissolved inorganic nutrients (ammonium, nitrate, nitrite, phosphate and silicate), the vertical light-attenuation coefficient $(K$, $\mathrm{m}^{-1}$ ) and phytoplanktonic primary production were measured. 
Physical measurements. Temperature was measured by a mercury thermometer. An optical handheld refractometer (Model 10419, Leica) was used to measure salinity. The light-attenuation coefficients were calculated by measuring the light intensity at the water's surface and at $0.3 \mathrm{~m}$ depth by a Skye PAR (photosynthetically active radiation) sensor. The attenuation coefficient $K\left(\mathrm{~m}^{-1}\right)$ was then calculated as:

$$
K=\left(\ln I_{\mathrm{o}}-\ln I_{\mathrm{z}}\right) / z
$$

where $I_{\mathrm{o}}$ and $I_{\mathrm{z}}$ are the light intensities at the surface and $0.3 \mathrm{~m}$, respectively (Nielsen \& Bresta 1984). The depth of the euphotic zone $\left(Z_{\text {eu }}\right)$ was calculated as the depth at which irradiance was $1 \%$ of the surface value, obtained from the attenuation coefficient $K\left(Z_{\text {eu }}=\right.$ $4.6 / K)$.

Determination of $Z_{\text {mix }}: Z_{\text {eu }}$ ratios. The depth of the deepest part of each sector (sampling sites) of the estuary at Brightlingsea, Aldboro Point, Wivenhoe and Hythe at high tide was calculated from UK Admiralty Chart No. 3741. The water column in the Colne Estuary is completely mixed (Ogilvie et al. 1997) and therefore the depth of the water column at each sampling site at high-tide was regarded as the depth of the mixed zone $\left(Z_{\text {mix }}\right)$. Then $Z_{\text {mix }}$ was divided by $Z_{\text {eu }}$ to obtain $Z_{\text {mix }}: Z_{\text {eu }}$ ratios.

Biomass. A cold methanol extraction technique was used for pigment analysis (Jensen 1978). A suitable volume of sample was filtered through Whatman GF/F filters and placed in methanol at $4^{\circ} \mathrm{C}$ in darkness for $24 \mathrm{~h}$ before measurement at 665 and $750 \mathrm{~nm}$.

Taxonomic composition of phytoplankton. Qualitative observations on the taxonomic composition of the phytoplankton community were made using light microscopy. To facilitate identification of diatoms, samples were fixed with glutaraldehyde $(50 \% \mathrm{v} / \mathrm{v})$ to $1 \%$ final concentration and acid-cleaned; permanent slides were prepared in Naphrax solution (Northern Biological Supplies).

Dissolved inorganic nutrients. Water samples collected for dissolved inorganic nutrient analyses were filtered through Whatman GF/F filters and frozen in liquid nitrogen before storing at $-20^{\circ} \mathrm{C}$ until analysed. Nitrate, nitrite, phosphate and silicate were analysed according to Parsons et al. (1984). Ammonium concentration was measured using a modification of the indophenol blue method (Harwood \& Kuhn 1970) with di-isochlorocyanurate replacing bleach as the chlorine donor (Krom 1980).

Primary production. The simulated in situ rate of primary production was measured by ${ }^{14} \mathrm{C}$-uptake (Nielsen \& Bresta 1984) with samples continuously mixed using a rolling incubator. The rolling incubation (75 rpm) prevented settlement of phytoplankton during the incubation period and simulated light condi- tions in the surface of the water column. This provided a better estimation of the simulated in situ rate of production at the surface, and in preliminary experiments yielded values of primary production $\sim 2.5$ fold higher than in a static incubation (data not shown). For each site, 4 light and 4 dark bottles $(250 \mathrm{ml}$, borosilicate glass) were filled with water from quadruplicate containers. Immediately before incubation, we added $100 \mu \mathrm{l} 5 \mathrm{Ci}\left(185 \mathrm{kBq}\right.$ ) ml $\mathrm{ml}^{-1} \mathrm{NaH}^{14} \mathrm{CO}_{3}$ solution (commercially prepared ampules, specific activity $1.85 \mathrm{GBq}$ $\mathrm{mmol}^{-1}$, pH 9.5: Dupont Nen) to each bottle, which was then placed on a rolling incubator in a temperaturecontrolled water bath situated outside under natural illumination. The temperature in the water bath was adjusted to the in situ temperature of the site by a thermo-circulator (Betta-Tech controls, Milton Keynes, $\mathrm{UK}$ ). Incubations lasted $2 \mathrm{~h}$ over midday (11:00 to 13:00 h) under natural daylight. At the end of the incubation, biological activity was stopped by adding glutaraldehyde solution $(50 \% \mathrm{v} / \mathrm{v})$ to the samples (to a final concentration of $1 \% \mathrm{v} / \mathrm{v})$. Samples were filtered through Whatman GF/F. After filtration, filters were washed with filtered site water, drained, and then exposed to fumes of concentrated hydrochloric acid in a desiccator to remove residual inorganic ${ }^{14} \mathrm{C}$.

To measure assimilated ${ }^{14} \mathrm{C}$ present in the dissolved organic carbon (DOC) leaked from cells, the filtrate from each sample was acidified to $\mathrm{pH}<2$ and purged with air to remove residual inorganic ${ }^{14} \mathrm{C}$. Subsamples $(1 \mathrm{ml})$ of filtrate and filter papers with algal cells were placed in $20 \mathrm{ml}$ plastic vials which were then filled with scintillation liquid (Optiphase Safe, LKB Wallac). Radioactivity was counted on a liquid scintillation counter (1217 Rack Beta, LKB Wallac). Any quenching was corrected by using an external standard.

Total carbon dioxide. Carbonate alkalinity and all forms of carbon dioxide were determined according to Parsons et al. (1984) on the day of sampling.

$\boldsymbol{P E}$ curve experiments. Photosynthesis vs irradiance $(P E)$ curves were determined on samples from the Hythe on a number of occasions over the annual primary production cycle. This site was chosen as the sampling site on the basis of its having the highest chl a concentration throughout the study. For the $P E$ incubations, a range of light intensities $(1425,838,540,271$ and $0 \mu \mathrm{mol} \mathrm{m} \mathrm{m}^{-2} \mathrm{~s}^{-1}$ ) were used (tungsten lamps). Triplicate light and dark bottles were incubated for $2 \mathrm{~h}$ and processed as for simulated in situ primary production measurements.

Determination of light-saturated zone as a percentage of mixed depth. Surface irradiance measurements at 30 min intervals on each day between September 1994 and November 1995 were obtained (Essex University data). The average solar noon irradiances (Sm, solar midday) for each day of each month were 
obtained from these data, and the total daily insolation $\left(\mathrm{mol} \mathrm{d}^{-1}\right)$ was calculated as:

$$
\text { Daily total } \left.\left(\mathrm{mol} \mathrm{d}^{-1}\right)=\left[(2 n / \pi) / 10^{6}\right)\right] S_{\mathrm{m}}
$$

where $n$ is the average daylight length in seconds for the particular month in question, and $S_{\mathrm{m}}$ is the monthly

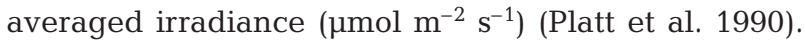
Total daily insolation was converted into mean daily irradiance ( $\mu \mathrm{mol} \mathrm{m} \mathrm{m}^{-2} \mathrm{~s}^{-1}$ ) by dividing by average monthly daylength. Average daily surface irradiance was integrated for $0.1 \mathrm{~m}$ depth intervals down the water column using the $K$ value for each month to obtain the average watercolumn irradiance for each site. The depth at which light was saturating (i.e. where irradiance was $>I_{\mathrm{m}}$ ) was regarded as the bottom of the light-saturated zone. The saturating light intensities $\left(I_{\mathrm{m}}\right)$ were obtained from the $P E$ curve experiments (see above).

Statistical analysis. Environmental variables were analysed using 2-way ANOVAs (site and time as factors) to determine significant spatial and temporal patterns. The percentage of the total sum of squares (SS) was used to determine the contribution of spatial and temporal patterns of variation in the data. Pearson's correlation coefficients determined correlations between nutrient concentrations and algal biomass, while Spearman's rank correlation (non-parametric) was used to determine significant correlations between water-column light climate ( $K, Z_{\text {mix }}: Z_{\text {eu }} I$, etc.) and phytoplankton (chl a, primary production, $P^{\mathrm{B}}$ ) variables.

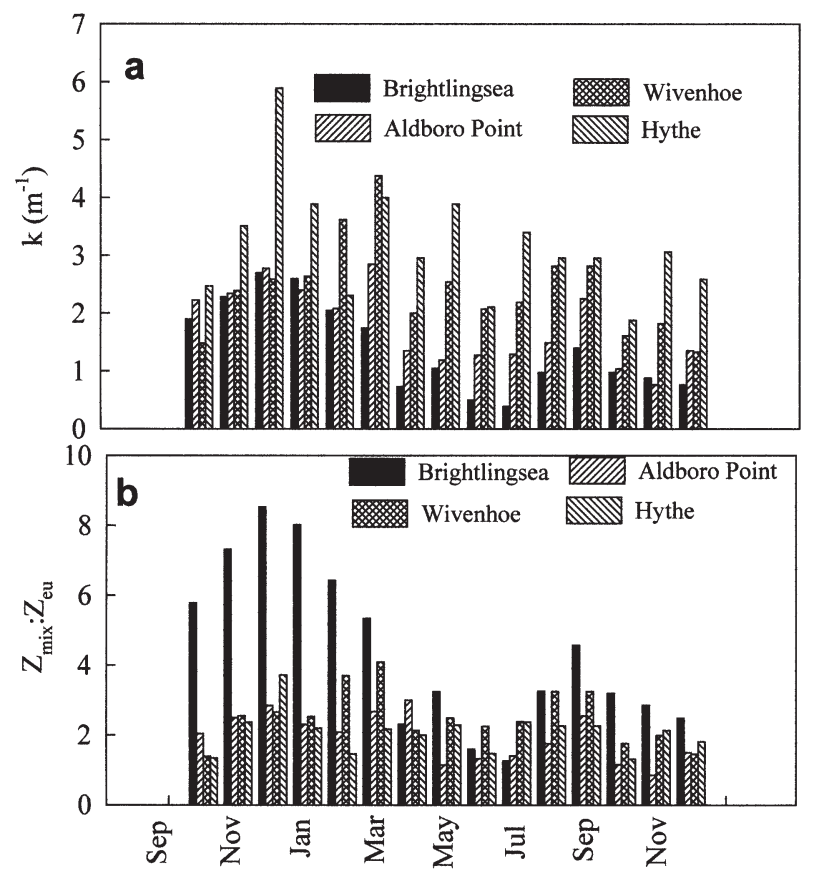

Fig. 2. Seasonal changes (between September 1994 and November 1995) in (a) vertical light-attenuation coefficient $\left(K \mathrm{~m}^{-1}\right)$ and (b) critical mixing ratio $\left(Z_{\text {mix }}: Z_{\text {eu }}\right)$ at 4 sites in the Colne Estuary

\section{RESULTS}

\section{Physical measurements}

The average winter (November to March) and summer (April to October) temperatures were 7.6 and $16^{\circ} \mathrm{C}$, respectively. There was no significant difference in water temperature between sites along the estuary. Salinity varied between 0 and 33 along the estuary at high tide. Vertical light-attenuation coefficients $\left(\mathrm{K} \mathrm{m}^{-1}\right)$ ranged from 0.39 to 5.89 , with a general decrease down the estuary (mean annual values of 3.2, 2.4, 1.8 and 1.4 at the 4 sites, respectively). Annual variation in $K$ was greatest at Brightlingsea (coefficient of variation, $\mathrm{CV}$, of annual mean $=55 \%$ ), with an order of magnitude decrease in $K$ values between December/ January and June/July of almost 1. At the Wivenhoe and Hythe sites, seasonal variation in $K$ was much less (CV 31 to $33 \%$ ) (Fig. 2a). The depth of the euphotic zone (depth of $1 \%$ light ) increased down the estuary from an annual mean $Z_{\text {eu }}$ of $1.5 \mathrm{~m}$ at Hythe to $4.5 \mathrm{~m}$ at Brightlingsea.

$Z_{\text {mix }}: Z_{\text {eu }}$ ratios varied between 8.5 in November 1994 at Brightlingsea and 0.85 in October 1995 at Aldboro Point. In general, at the 4 sites, $Z_{\text {mix }}: Z_{\text {eu }}$ ratios were higher during winter than summer; and were higher in the lower estuary, where the water column was on average deeper than in the upper estuary (Fig. 2b). $Z_{\text {mix }}: Z_{\text {eu }}$ ratios were significantly correlated $\left(\mathrm{r}_{\mathrm{s}}=0.32\right.$, $\mathrm{p}<0.05)$ with $K$ values.

\section{Dissolved inorganic nutrients}

The concentrations of all the major dissolved inorganic nutrients (ammonium, nitrate, phosphate and silicate (Fig. 3) showed significant spatial and temporal variation (ANOVA, p < 0.001) along the Colne Estuary (Table 1). Common to each nutrient was a concentration gradient decreasing down the estuary as salinity increased, with concentrations of nutrients sometimes 2 orders of magnitude higher at the head of the estuary compared to the mouth (Fig. 3).

Differences between sites (Fig. 3a) were responsible for the greatest amount of variation in ammonium concentrations $(67 \%, \mathrm{p}<0.001)$ while seasonal changes accounted for $\sim 17 \%$ of the variance in ammonium concentration (Table 1). The maximum ammonium concentration measured was $291 \mu \mathrm{M}$ at the Hythe in July 1994 (Fig. 3a), with values as low as $2 \mu \mathrm{M}$ at Brightlingsea on the same sampling day.

Spatial variation between sites accounted for $41 \%$ of the variance in nitrate concentrations (Fig. 3b). Nitrate concentrations showed a much stronger seasonal pattern $(49 \%$ of variance: Table 1$)$ than ammonium, with 

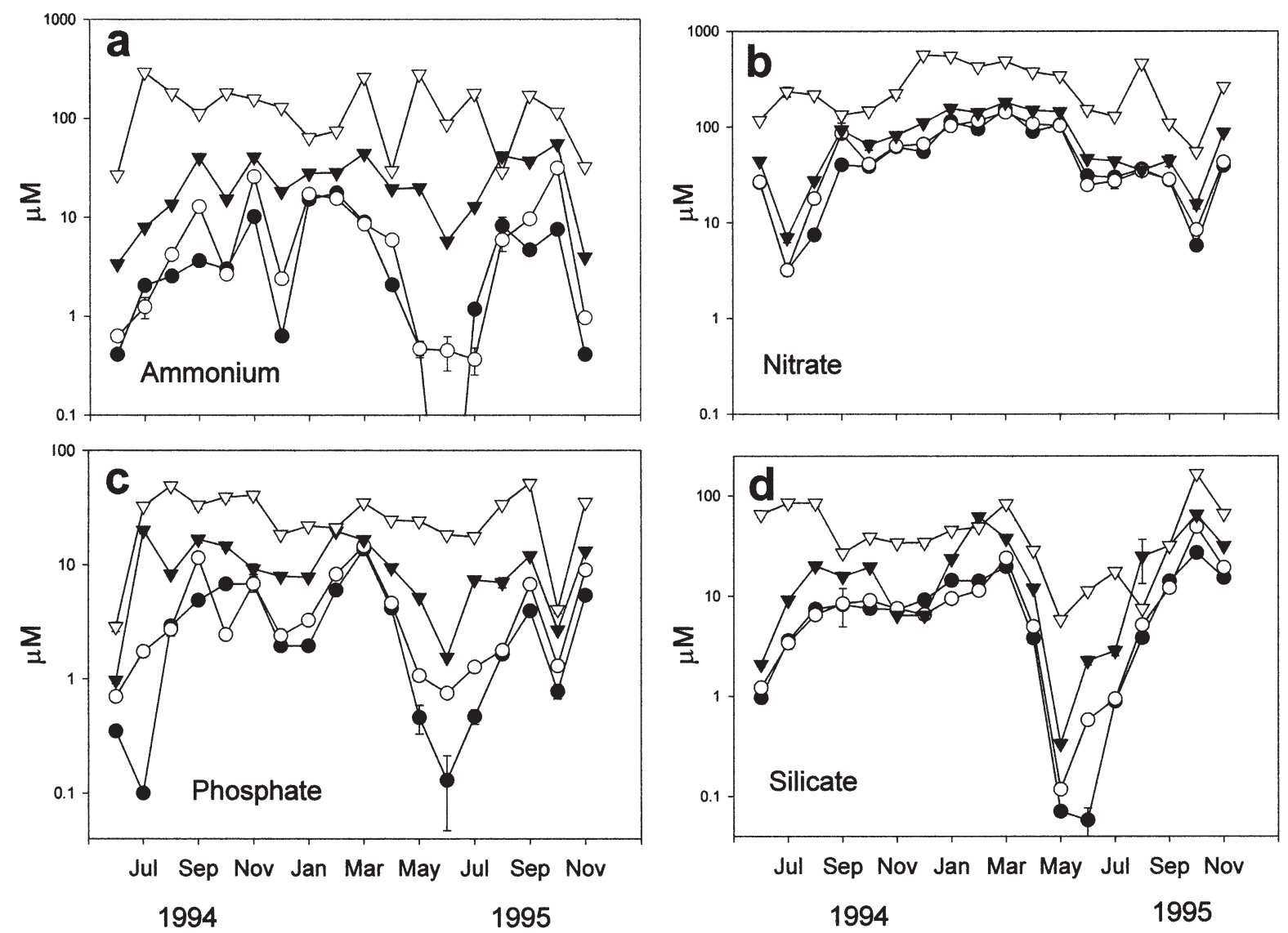

Fig. 3. Seasonal (mean $\pm \mathrm{SD}, \mathrm{n}=4$ ) variation in dissolved ammonium, nitrate, phosphate and silicate at 4 sampling sites sites along the Colne Estuary between June 1994 and November 1995 (note different $y$-axis scales). (๑) Brightlingsea; (O) Aldboro Point;

$(\nabla)$ Wivenhoe; $(\nabla)$ Hythe

higher concentrations present during the winter and spring months. Nitrate concentrations varied between $5.75 \mu \mathrm{M}$ at Brightlingsea in October 1995 and $564 \mu \mathrm{M}$ at the Hythe in December 1994. Nitrate was by far the most abundant form of inorganic nitrogen in the estuary, and was also present in much higher molar concentrations than other dissolved nutrients (Fig. 3).

Phosphate concentrations varied between $0.1 \mu \mathrm{M}$ (in July 1994 at Brightlingsea) to $52 \mu \mathrm{M}$ (in September 1995 at Hythe). Variation in phosphate concentration was largely due to spatial differences $(55 \%$ of variation), with higher concentrations at the head of the estuary. There was a significant decrease in phosphate concentrations in the estuary during the period April to June, particularly at the 3 lower estuary stations, with concentrations falling below $1 \mu \mathrm{M}$ at Brightlingsea and Aldboro Point (Fig. 3c).

Seasonal differences accounted for $50 \%$ of the variance in silicate concentrations (Table 1), with peak silicate concentrations in early spring and in mid-autumn at Hythe (88 and $168 \mu \mathrm{M}$, respectively: Fig. 3d). High concentrations of silica in early spring (late February and March) decreased sharply between April and June (concentrations $<0.1 \mu \mathrm{M}$ at Brightlingsea and Aldboro Point) before increasing in the later summer period. With the single exception of October 1995 at Brightlingsea and Aldboro Point, N:Si ratios along the estuary throughout the sampling period were above the Redfield N:Si ratio of 1 , attaining a maximum of $>1400$ in May 1995 at Brightlingsea (Table 2).

\section{Phytoplankton biomass and taxonomic composition}

Chl a concentrations varied between $0.5 \mu \mathrm{g} \mathrm{chl} \mathrm{a} \mathrm{l^{-1 }}$

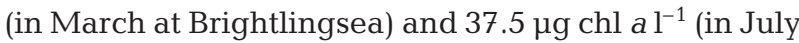
1995 at Hythe). Water-column chl a exhibited a clear seasonal pattern, with lowest values measured at all sites between January and March 1995, after which there was an increase in chl a to peak values in July (Fig. 4a). This seasonal pattern of variation accounted for $75 \%$ of the variance in chl a concentration data (Table 1), but there were also significant site and site $x$ time effects, with higher concentrations of chl $a$ at the 
head of the estuary than at the seaward end in all months except December to February (Fig. 4a). Maximum chl a concentrations were measured at Hythe in July 1995 in a phytoplankton community largely consisting of flagellated euglenophytes (12 to $47 \mu \mathrm{m}$ in

Table 1. Two-way ANOVA of variables measured in the Colne Estuary between September 1994 and November 1995. The percentage of the total sum of squares (SS) explained by each factor within the ANOVA is given. All $F$-values are significant at $\mathrm{p}<0.001$

\begin{tabular}{|llrcr|}
\hline Variable & Factor & df & \% of total SS & $F$ \\
\hline $\mathrm{NH}_{4}{ }^{+}$ & Time & 14 & 16.6 & 451 \\
& Site & 3 & 67 & 8533 \\
& $\mathrm{~T} \times \mathrm{S}$ & 42 & 16 & 145 \\
$\mathrm{NO}_{3}{ }^{-}$ & Time & 14 & 49 & 1093 \\
& Site & 3 & 42 & 4297 \\
& $\mathrm{~T} \times \mathrm{S}$ & 42 & 9 & 64 \\
$\mathrm{PO}_{4}{ }^{-}$ & Time & 14 & 34 & 1590 \\
& Site & 3 & 51 & 1100 \\
$\mathrm{SiO}_{3}{ }^{-}$ & $\mathrm{T} \times \mathrm{S}$ & 42 & 15 & 226 \\
& Time & 14 & 66 & 3989 \\
& Site & 3 & 27 & 7553 \\
$\mathrm{Chl}^{a} \mathrm{a}$ & $\mathrm{T} \times \mathrm{S}$ & 42 & 8 & 156 \\
& Time & 14 & 76 & 1382 \\
& Site & 3 & 14 & 1169 \\
Primary & $\mathrm{T} \times \mathrm{S}$ & 42 & 10 & 62 \\
production & Time & 14 & 92 & 3636 \\
& Site & 3 & 1 & 189 \\
& T $\times \mathrm{S}$ & 42 & 7 & 87 \\
\hline
\end{tabular}

Table 2. N:Si ratios at 4 sampling sites between June 1994 and November 1995 in the Colne Estuary

\begin{tabular}{|lcrrr|}
\hline Date & Brightlingsea & $\begin{array}{c}\text { Aldboro } \\
\text { Point }\end{array}$ & Wivenhoe & Hythe \\
\hline \multicolumn{5}{c}{} \\
$\mathbf{1 9 9 4}$ & & & \\
Jun & 27.48 & 22.30 & 22.74 & 2.11 \\
Jul & 1.44 & 1.30 & 1.64 & 6.15 \\
Aug & 1.34 & 3.42 & 2.06 & 4.67 \\
Sep & 5.32 & 11.63 & 8.48 & 5.40 \\
Oct & 5.16 & 4.79 & 4.12 & 8.48 \\
Nov & 9.80 & 11.84 & 19.05 & 11.16 \\
Dec & 6.09 & 10.47 & 19.99 & 20.16 \\
1995 & & & & \\
Jan & 8.97 & 12.69 & 7.81 & 11.48 \\
Feb & 7.99 & 11.64 & 7.34 & 10.00 \\
Mar & 8.15 & 6.32 & 5.96 & 8.94 \\
Apr & 23.96 & 22.96 & 14.07 & 14.09 \\
May & 1480.9 & 877.4 & 489.08 & 106.64 \\
Jun & 530.6 & 43.18 & 23.06 & 21.20 \\
Jul & 34.76 & 29.27 & 8.20 & 12.47 \\
Aug & 11.55 & 7.73 & 3.07 & 65.33 \\
Sep & 2.31 & 3.13 & 2.56 & 8.73 \\
Oct & 0.49 & 0.81 & 1.09 & 1.02 \\
Nov & 2.61 & 2.28 & 2.88 & 4.48 \\
& & & & \\
\hline
\end{tabular}

length). Flagellates were the major components of the phytoplankton in all seasons, although their abundance decreased in winter. Qualitative observation also revealed evidence of some resuspension of benthic epipelagic diatoms (e.g. Cylindrotheca closterium, Nitzschia spp. and Navicula spp.) in the water column throughout the year along the estuary, particularly at the 2 upper sampling sites. The relative abundance of benthic diatoms was highest during spring and decreased in the summer, but generally diatoms were relatively rare (compared to flagellates) within the phytoplankton. There were significant positive correlations $(p<0.01)$ between chl a concentrations and ammonium and phosphate concentrations and temperature $\left(\mathrm{r}^{2}=0.29,0.19\right.$ and 0.55 , respectively, $\left.\mathrm{n}=240\right)$ over the 15 mo study period. Water-column chl a concentrations were positively correlated with daily and water-column irradiance (Table 3).

\section{Phytoplanktonic primary production}

The magnitude of simulated surface phytoplanktonic primary production (measured at in situ temperatures under natural illumination) varied during the study between $0.64 \times 10^{-3} \mathrm{gg} \mathrm{C}^{-1} \mathrm{~h}^{-1}$ (in February at Brightlingsea) and $\sim 17 \mu \mathrm{C} \mathrm{Cl}^{-1} \mathrm{~h}^{-1}$ (in August at Hythe) (Fig. 4b). Seasonal changes accounted for $92 \%$ of the variation in primary production, with a minimum in primary production during February, followed by a period of almost exponential increase to peak values in August (Fig. 4b). Spatial differences along the estuary explained only $1 \%$ of the variation in the primary production data over the 15 mo period, but during the period of rapid increase in primary production there were significantly higher $(p<0.01)$ rates of primary production towards the head of the estuary (Fig. 4b). Primary production rates were significantly correlated with chl a $\left(\mathrm{r}_{\mathrm{s}}=0.63, \mathrm{p}<0.001\right)$, and with incident and integrated water column irradiance values (Table 3 ).

The losses of fixed carbon into the DOC pool after $2 \mathrm{~h}$ primary production incubation ranged between 0.87 and $27 \%$. Losses of ${ }^{14} \mathrm{C}$ into the DOC pool were lower during the period of high rates of primary production (June to September, range 0.87 to $5 \%$ ) than the rest of the year. There were no significant spatial patterns in \% DOC, and average loss of ${ }^{14} \mathrm{C}$ into the DOC pool was $8.8 \%$.

Biomass-specific primary production $\left(P^{\mathrm{B}}, \mu \mathrm{gC} \mu \mathrm{g}^{-1}\right.$ $\mathrm{chl} a \mathrm{~h}^{-1}$ ) showed a seasonal trend similar to that of primary production (Fig. 5a), $P^{\mathrm{B}}$ values ranged between $4 \times 10^{-4} \mu \mathrm{gC} \mathrm{gg}^{-1} \mathrm{chl} \mathrm{a} \mathrm{h}{ }^{-1}$ (in February at Brightlingsea) and $3 \mu \mathrm{gC} \mathrm{gg}^{-1} \mathrm{chl} \mathrm{a} \mathrm{h} \mathrm{h}^{-1}$ (in August at Wivenhoe). During the initial autumn period, $P^{\mathrm{B}}$ was significantly higher at the downstream sites (Aldboro and 

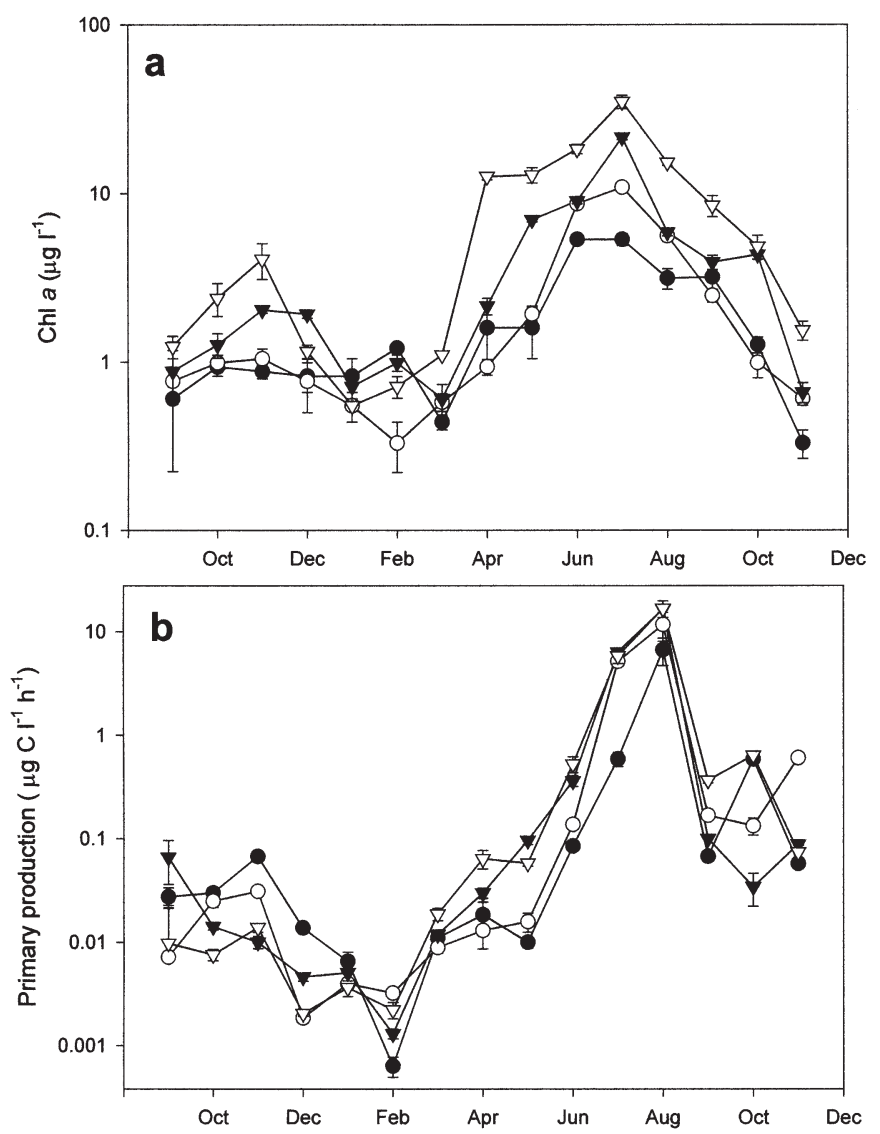

Fig. 4. Seasonal and spatial changes (mean $\pm \mathrm{SD}, \mathrm{n}=4$ ) in (a) chl a concentrations and (b) primary production at 4 sampling sites along the Colne Estuary between September 1994 and November 1995. Symbols as in Fig. 3

Brightlingsea), although by December this pattern had disappeared. There was a similar exponential increase in $P^{\mathrm{B}}$ from April to August (Fig. 5a). $P^{\mathrm{B}}$ was correlated with both primary production and chl a concentrations $\left(\mathrm{r}_{\mathrm{s}}=0.83,0.36, \mathrm{p}<0.001,0.05\right.$, respectively $)$, but also showed a significant negative correlation with lightattenuation, $K$ (Table 3 ).

Light-saturated rates of primary production $\left(P_{\max }^{\mathrm{B}}\right)$ obtained from $P E$ curves were generally greater than $P^{\mathrm{B}}$ measured under natural illumination conditions (Fig. 5a), except during August and October 1995. $I_{\mathrm{m}}$ values were always higher than the calculated average integrated light intensity in the water column at each site (Fig. 5b), and in late summer $I_{\mathrm{m}}$ and the average daily surface irradiance were similar. The percentage of the mixed depth $\left(Z_{\text {mix }}\right)$ at which irradiance was $>I_{\mathrm{m}}$ ranged between 2.7 and 21.6 throughout the period of study. There was a significant increase up the estuary in the percentage of the water column in which $I>I_{\mathrm{m}}(F=9.5, \mathrm{p}<0.001)$, with the lowest values at Brightlingsea (Fig. 6).

\section{DISCUSSION}

The rates of primary production, biomass, and dissolved inorganic nutrient concentrations showed significant seasonal and spatial variation in the Colne Estuary (Table 1). The seasonal changes in production and biomass were very similar, with higher values during summer. This reflected the fact that, in general, seasonally driven changes such as light conditions in the water column regulated both primary production and phytoplankton biomass. The peaks in primary production and biomass occurred in August and July, respectively. The occurrence of a spring (usually diatom-dominated) and summer peak in both phytoplankton biomass and production is common in temperate estuaries (e.g. Malone et al. 1996, Marker \& Collett 1997), but there was no distinct spring bloom in the Colne Estuary (Fig. 4). Rather, production and algal biomass began to increase during March and April and remained at their highest levels during the summer, a scenario indicative of light-limited situations (van Spaendonk et al. 1993). Decreases in production and biomass after the spring bloom are usually attributed to nutrient limitation, increased grazing or parasitism. The Colne Estuary shows clear seasonal patterns in nutrient concentrations, primarily due to seasonal changes in the inputs of nutrients from the river and sewage treatment works (Dong et al. 2000). In the upper reaches of the estuary, nutrient concentrations far exceed those usually considered limiting to algal growth. Kromkamp \& Peene (1995) suggested that although primary production in estuaries can be high in comparison to nearby coastal areas due to relatively high nutrient concentrations, this may not always be

Table 3. Spearman's rank-correlation coefficients between water-column light climate and phytoplankton variables $\left(\mathrm{n}=60\right.$; ns: not significant, ${ }^{*} \mathrm{p}<0.05,{ }^{* *} \mathrm{p}<$ $\left.0.01,{ }^{* * *} \mathrm{p}<0.001\right) . P^{\mathrm{B}}$ : biomass-normalised production

\begin{tabular}{|c|c|c|c|c|}
\hline Variable & $\begin{array}{l}\text { Mean daily } \\
\text { irradiance }\end{array}$ & $\begin{array}{c}\text { Mean water- } \\
\text { column irradiance }\end{array}$ & $\begin{array}{l}\text { Light attenuation } \\
\qquad\left(K \mathrm{~m}^{-1}\right)\end{array}$ & $Z_{\text {mix }}: Z_{\text {eu }}$ \\
\hline $\begin{array}{l}\text { Chl a } \\
\left(\mu \mathrm{g} \mathrm{l}^{-1}\right)\end{array}$ & $0.49^{* * *}$ & $0.48^{* * *}$ & $0.13 \mathrm{~ns}$ & $-0.1 \mathrm{~ns}$ \\
\hline $\begin{array}{l}\text { Primary production } \\
\left(\mu \mathrm{C} \mathrm{C}^{-1} \mathrm{~h}^{-1}\right)\end{array}$ & $0.31^{*}$ & $0.32^{*}$ & $-0.20 \mathrm{~ns}$ & $-0.12 \mathrm{~ns}$ \\
\hline $\begin{array}{l}P^{\mathrm{B}} \\
\left(\mu \mathrm{gC} \mu \mathrm{g} \operatorname{chl} a^{-1} \mathrm{~h}^{-1}\right)\end{array}$ & $0.17 \mathrm{~ns}$ & $0.19 \mathrm{~ns}$ & $-0.36^{* *}$ & $-0.17 \mathrm{~ns}$ \\
\hline
\end{tabular}



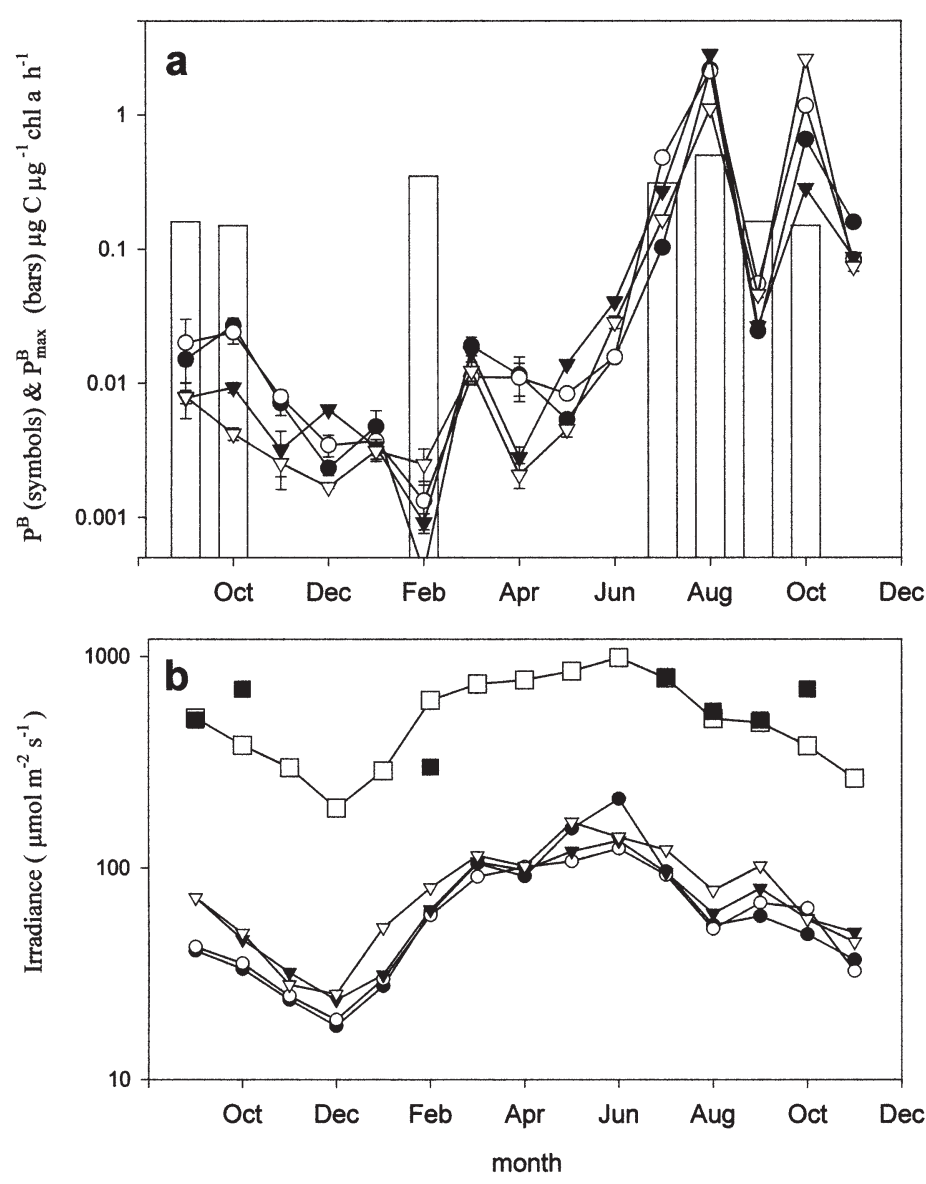

Fig. 5. (a) Chl a-normalised primary production $\left(P^{\mathrm{B}}\right)$ at 4 sampling sites sites between September 1994 and November 1995 compared to $P_{\text {max }}^{\mathrm{B}}$ (open bars) derived from PE curves of phytoplankton from Hythe; (b) seasonal variation in average daily surface irradiance ( $\square$ ) and average daily depthintegrated irradiance at 4 sampling sites compared to $I_{\mathrm{m}}(\boldsymbol{\square})$ values for phytoplankton obtained from PE (photosynthesis vs irradiance) curves. Other symbols as in Fig. 3

the case since estuaries, especially the well-mixed coastal plain systems, are often very turbid, imposing light limitation on production. Similarly in the Delaware Estuary, despite high anthropogenic nutrient inputs, changes such as shifts in phytoplankton species composition, high chl a concentrations and depressed oxygen concentrations have not been observed, because of light-limitation of algal production (Pennock 1985). In the Colne Estuary, chl a concentrations did not reach levels typical of nuisance algal blooms. Chl a concentrations were always $<50 \mu \mathrm{g} \mathrm{l}^{-1}$, with an annual mean of $\sim 5 \mu \mathrm{g} \mathrm{l^{-1 }}$, which is at the lower end of the range for estuarine habitats (Heip et al. 1995). This was much lower than in other nearby estuaries (e.g. Great Ouse Estuary: Rendell et al. 1997), despite high nutrient concentrations, especially in the upper reaches, all year round.
There were some seasonal changes in the broad composition of the algae in the estuary. Spring phytoplankton displayed an increased abundance of diatoms compared to the rest of the year, and there was a clear decrease in silicate concentrations during this period of increasing chl $a$ and primary production (Figs. 3 \& 4). Diatoms disappeared from the summer phytoplankton community, possibly due to silicate limitation, and the species composition shifted to an assemblage rich in flagellates. Silicate concentrations in the Colne at the end of winter period were comparable with concentrations in the Chesapeake Estuary, USA, which showed a similar pattern of spring decline of silicate coincident with diatom growth (Conley \& Malone 1992). Similar species shifts during the growing season have been observed in other estuaries (Bakker et al. 1994). A change from diatom-dominated to flagellate-dominated phytoplankton communities is also a feature of coastal eutrophication and the development of nuisance algal blooms (Underwood \& Kromkamp 1999). Even though large standing stocks of phytoplankton did not develop, the conditions in the Colne (high nutrient concentrations, low light availability) appear to favour the dominance of flagellates,.

The N:Si ratios in the Colne were always $>1$, indicating a potential stoichiometric limitation by silicate. Such potential limitation of biomass would occur in an algal community only if silicate dropped to limiting concentrations, when diatoms would be replaced by flagellates, with possible consequences to the food chains in the estuary. Franzs (1986) reported that increased nutrient discharge from the Rhine, Meuse and Scheldt rivers had multiplied the summer flagellate blooms in Dutch coastal waters by a factor of 2 to 4 since 1930, and had caused a shift in dominance from diatoms to other algae. Similarly, in the northern Adri-

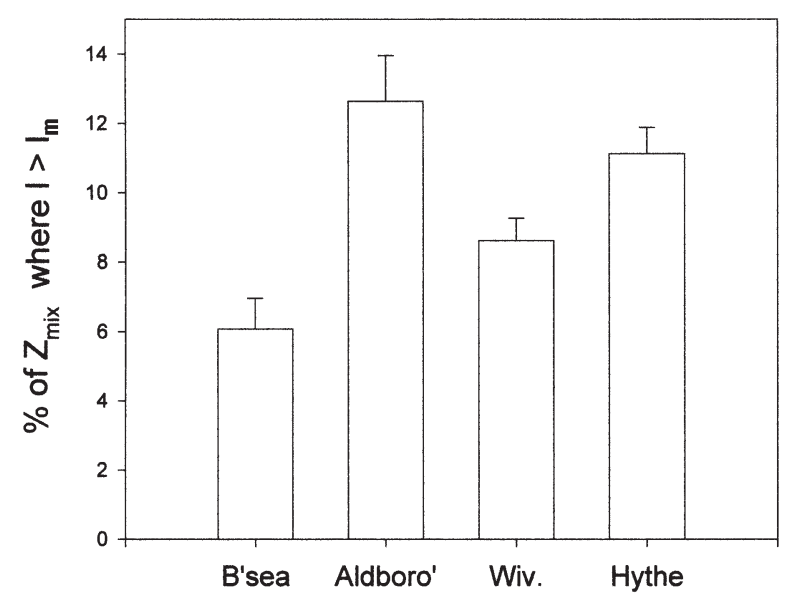

Fig. 6. Percentage of the mixed depth $\left(Z_{\text {mix }}\right)$ at which mean daily irradiance was $>I_{\mathrm{m}}$ at 4 sites in the Colne Estuary 
atic Sea and the northern Gulf of Mexico, the changes in $\mathrm{N}: \mathrm{P}$ and $\mathrm{Si}: \mathrm{P}$ ratios over a $30 \mathrm{yr}$ period resulted in these systems becoming potentially less limiting in terms of $\mathrm{N}$ and $\mathrm{P}$ but more Si-limited (Justic et al. 1995). Justic et al. (1995) hypothesised that silicon deficiency might be exacerbating eutrophication by reducing the role of diatoms in coastal food webs. More recent evidence comes from the River Danube, where Humborg et al. (1997) reported a decrease in silicate concentration and increase in $\mathrm{N}$ and $\mathrm{P}$ inputs due to damming of the river. This has resulted in dramatic shifts in the phytoplankton composition from diatoms (siliceous) to coccolithophores and flagellates (nonsiliceous).

Another possible reason for the general lack of diatoms in the phytoplankton community in the Colne Estuary during the summer could be decreased resuspension of bottom sediments due to reduced wind energy. Resuspension of benthic microalgae by tidal and wind-induced currents has been shown to contribute up to $25 \%$ of the suspended chl $a$ in the Ems Estuary (de Jonge \& van Beusekom 1995), while in the turbid Gironde Estuary the strong correlation between chl a concentration and suspended particulate material suggested an important influence of resuspension on the distribution of chl $a$ in the turbidity maximum zone (Irigoien \& Castel 1997).

The seasonal trend in $P^{\mathrm{B}}$ was similar to that in primary production, with higher values during the summer; but while over the whole period of study primary production was significantly correlated with irradiance, $P^{\mathrm{B}}$ showed no significant correlation with $I$. So although biomass and primary production began to increase in March/April (correlated with increases in average irradiance), major changes in $P^{\mathrm{B}}$ did not occur until June. By July and August, $P^{\mathrm{B}}$ values were close to the $P_{\text {max }}^{\mathrm{B}}$ values reflected in the $P E$ curves (Fig. 5a), indicating that at this time algal photosynthesis was not light-limited at the surface of the water column. During the rest of the year, $P^{\mathrm{B}}$ was lower than $P_{\max }^{\mathrm{B}}$ indicating that phytoplankton were not photosynthesising at their physiological maximum potential rate for most of the year. The values of $P_{\text {max }}^{\mathrm{B}}$ measured in the Colne Estuary were lower than in other comparable studies (Kromkamp \& Peene 1995). $P_{\text {max }}^{\mathrm{B}}$ values were not directly related to temperature, peaking some time after the highest water temperatures in July (see Kocum et al. 2002, this issue, for further dicussion).

Comparision of the $I_{\mathrm{m}}$ and $K$ values and the mean daily incident and depth-integrated water-column irradiance showed that, on average, $<14 \%$ of the mixed zone depth was light-saturated throughout the sampling period in the estuary. This is an avarage based on mean daily irradiance, so at times during the daily insolation cycle, saturating light intensities would

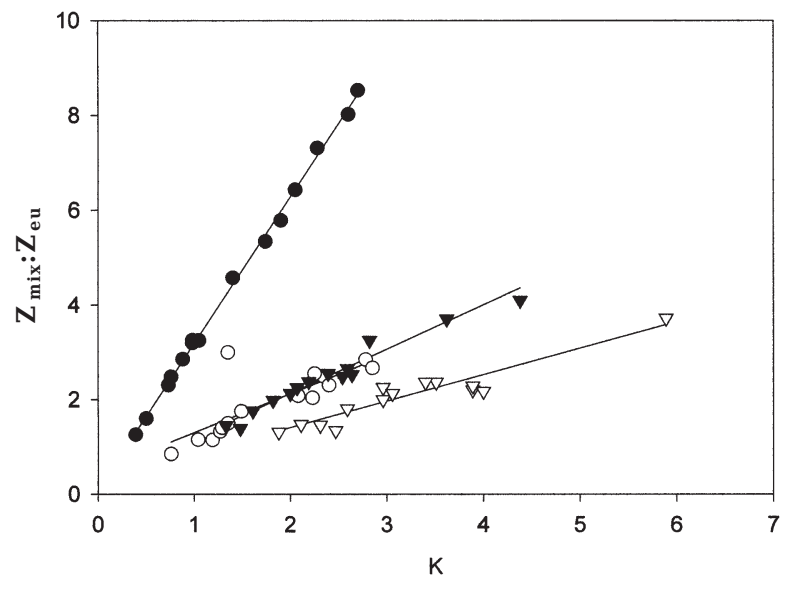

Fig. 7. Relationship between the light-attenuation coefficient $\left(K \mathrm{~m}^{-1}\right)$ and the $Z_{\text {mix }}: Z_{\text {eu }}$ ratio at 4 sampling site in the Colne Estuary. Symbols as in Fig. 3

be present further down the water column. Light attenuation coefficients in the Colne Estuary were high, especially in the upper reaches, resulting in a shallow euphotic zone $\left(Z_{\text {eu }}\right)$. This might indicate the possibility of increased light limitation up the estuary. However, $Z_{\text {mix }}: Z_{\text {eu }}$ ratios were lower in the upper estuary as a result of a shallow water-column depth (Fig. 7). The $Z_{\text {mix }}: Z_{\text {eu }}$ ratio relates the depth of the mixed layer to the euphotic zone, and thus gives some indication of the average time spent by the algae in the dark and in the light. With larger $Z_{\text {mix }}: Z_{\text {eu }}$ ratios, the average time spent by algae in the light decreases, and thus net photosynthesis decreases. Grobbelaar (1990) suggested that the $Z_{\text {mix }}: Z_{\text {eu }}$ ratio would be the most important factor affecting phytoplankton production in turbid ecosystems, which usually have large $Z_{\text {mix }}: Z_{\text {eu }}$ ratios. Furthermore, Cloern (1996) suggested that blooms often develop when the effective mixing depth of the water column is reduced by vertical stratification, thereby decreasing the ratio. Values of $Z_{\text {mix }}: Z_{\text {eu }}<5$ to 20 have been proposed as necessary for net primary production to occur in an ecosystem (Wofsy 1983, Cloern 1987, 1996, Grobbelaar 1990). In the Colne Estuary, the $Z_{\text {mix }}: Z_{\text {eu }}$ ratios varied only between 0.85 and 8.5, and increased down the estuary as the water depth increased (Fig. 2). The only site which under these criteria could be considered to approach light limitation (i.e. no net primary production; ratio $>5$ according to Wofsy 1983) was Brightlingsea during the winter months (Fig. 2). However, while calculations of critical mixing ratios may indicate the potential for net community growth, they take no account of absolute light levels in the water column. Comparisons of $P^{\mathrm{B}}$ values with $P_{\max }^{\mathrm{B}}$ and averaged water-column irradiance with $I_{\mathrm{m}}$ values show that on average, light would 
have been a major limiting factor for photosynthesis in the water column for the whole period studied. Yet, during particular periods during the summer months, there would have been times when photosynthesis was light-saturated during the daily insolation curve. Interestingly, highest chl $a$, primary production and $P^{\mathrm{B}}$ values were measured in the turbid upper parts of the estuary at the Hythe (mean annual $Z_{\text {eu }}=1.5 \mathrm{~m}$ ). Thus, at the Hythe, in the absence of nutrient limitation, the low $Z_{\text {mix }}: Z_{\text {eu }}$ ratio due to the shallowness of the water column permitted high production rates despite the high turbidity (Fig. 7). Since the $Z_{\text {mix }}: Z_{\text {eu }}$ ratio was much higher at the seaward end of the Colne Estuary at Brightlingsea, phytoplankton were on average subject to greater light-limitation in the clearer lower estuary than in the more turbid upper estuary, especially during winter. This apparent paradox was due to the fact that the water column in the Colne is completely mixed and stratification does not occur (Ogilvie et al. 1997). Thus, in contrast to what high $K$ values intuitively indicate, there was less possibility of light-limitation in the shallow upper estuary than in the deeper lower estuary (Fig. 7). Although they did not measure primary production, Fichez et al. (1992) also showed that in the Great Ouse Estuary, UK, there was evidence of development of primary production in the shallow water despite a shallow euphotic zone and a totally mixed water column, and rationalised this in terms of the $Z_{\text {mix }}: Z_{\text {eu }}$ ratio. Van Spaendonk et al. (1993) found that in the Westerschelde Estuary, the Netherlands, high turbidity resulted in light-limited growth of phytoplankton, and calculated a high annual primary production (200 to $300 \mathrm{~g} \mathrm{C} \mathrm{m}^{-2}$ ) despite the fact that the vertical mixing zone was 5 times larger than the euphotic zone. They concluded that their result corroborated Grobbelaar's (1990) hypothesis that the value of the $Z_{\text {mix }}: Z_{\text {eu }}$ at which phytoplankton can still be effective producers can be seriously underestimated, and that phytoplankton can still cope effectively with turbid conditions when $Z_{\text {mix }}: Z_{\text {eu }}$ is $>20$.

An estimated annual rate of primary production was calculated for each of the 4 sites in the Colne Estuary using the formulae for chl a-normalised primary production $\left(P^{\mathrm{B}}, \mathrm{gC} \mathrm{g} \mathrm{chl} a^{-1} \mathrm{~h}^{-1}\right.$ : Cullen 1990), the mean chl a concentrations, water-column depth and lightintensity through the water column. This gave annual rates of 5.5, 4.2 and $4.3 \mathrm{gC} \mathrm{m}^{-2} \mathrm{yr}^{-1}$ for Brightlingsea, Aldboro Point and Wivenhoe, respectively, and $160.4 \mathrm{~g} \mathrm{C} \mathrm{m}^{-2} \mathrm{yr}^{-1}$ for Hythe. The mean annual production rates for each sector were multiplied by the area of water surface at mid-tide in the relevant sector of the estuary (Robinson 1996), all sectors were totalled, and then the total estuarine production was divided by the total area of estuary to derive an overall average production for the whole estuary. This was equivalent to
$8.9 \mathrm{~g} \mathrm{C} \mathrm{m}^{-2} \mathrm{yr}^{-1}$, placing the Colne Estuary at the lower end of the range of the estuarine annual production values given in Underwood \& Kromkamp (1999). The estuary is 'oligotrophic' in relation to the ranges of annual estuarine production suggested by Nixon (1995) despite the very high nutrient concentrations present. The outer Colne Estuary values were similar to those measured in the Bristol Channel by Joint \& Pomeroy (1981), where light is also limiting due to high turbidity.

In conclusion, our study showed that throughout the estuary algal photosynthesis was almost always lightlimited, even at the surface, with $P^{\mathrm{B}}<P^{\mathrm{B}}$ max except during late summer. In late summer at the water surface, factors other than light would regulate photosynthesis. However, in only 6 to $13 \%$ of the upper water column did average daily light intensity exceed $I_{\mathrm{m}}$, and even in late summer the algae throughout most of the water column would have been light-limited.

Despite higher turbidity, the critical mixing ratio ensured that phytoplankton cells were maintained more effectively in the higher light environments in the upper estuary than in the lower estuary. Even so, the average light intensity throughout the water column was far below $I_{\mathrm{m}}$, so that algal photosynthesis remained light-limited even where $Z_{\text {mix }}: Z_{\text {eu }}$ was low. However, the more beneficial light regime in the upper estuary, combined with excess of nutrients, maintained high algal biomass in the upper estuary despite the relatively rapid flushing time.

Acknowledgements. We would like to thank Mr. R. Littlewood and Mr. J. Green for their help with sample collection. E.K. was supported by a studentship from the Turkish Higher Educational Council to 'TC Canakkale Onsekiz Mart University.'

\section{LITERATURE CITED}

Baban SMJ (1997) Environmental monitoring of estuaries: estimating and mapping various environmental indicators in Breydon water estuary, UK, using landsat TM imagery. Estuar Coast Shelf Sci 44:589-598

Bakker C, Herman PMJ, Vink M (1994) A new trend in the development of the phytoplankton in the Oosterschelde (SW Netherland) during and after the construction of a storm surge barrier. Hydrobiologia 282/283:79-100

Cadee GC, Hegeman J (1974) Primary production of phytoplankton in the Dutch Wadden Sea. Neth J Sea Res 8(2): $240-259$

Cloern JE (1987) Turbidity as a control on phytoplankton biomass and productivity in estuaries. Cont Shelf Res $7(11 / 12): 1367-1381$

Cloern JE (1996) Phytoplankton bloom dynamics in coastal ecosystems: a review with some general lessons from sustained investigation of San Francisco Bay, California. Rev Geophys 34(2):127-168

Cole BE, Cloern JE (1984) Significance of biomass and light 
availability to phytoplankton productivity in San Francisco Bay. Mar Ecol Prog Ser 17:15-24

Cole BE, Cloern JE (1987) An emprical model for estimating phytoplankton productivity in estuaries. Mar Ecol Prog Ser 36:299-305

Conley DJ, Malone TC (1992) Annual cycle of dissolved silicate in Chesapeake Bay: implications for the production and the fate of phytoplankton biomass. Mar Ecol Prog Ser 81:121-128

Cullen JJ (1990) On models of growth and photosynthesis in phytoplankton. Deep-Sea Res 37:667-683

de Jonge VN, van Beusekom JEE (1995) Wind- and tideinduced resuspension of sediment microphytobenthos from the tidal flats in the Ems Estuary. Limnol Oceanogr 40(4):766-778

D'Elia CF, Sanders JG, Boynton WR (1986) Nutrient enrichment studies in a coastal plain estuary: phytoplankton growth in a large-scale, continuous culture. Can J Fish Aquat Sci 43:397-406

Doering PH, Oviatt CA, Nowicki BL, Klos LW, Reed LW (1995) Phosphorus and nitrogen limitation of primary production in a simulated estuarine gradient. Mar Ecol Prog Ser 124: 271-287

Dong LF, Nedwell DB, Underwood GJC, Sage AS (2000) Environmental limitations of phytoplankton in estuaries. Final Report UK Department of Environment, Transport and the Regions, No CW0694. DEFRA, London

Elliott M, de Jonge VN, Burrell KL, Johnson MW, Philips GL, Turner TM (1993) Trophic status of the Ore/Alde, Deben, Stour and Colne estuaries. Report to the National Rivers Authority, UK, University of Hull. Environmental Agency, Peterborough

Fichez R, Jickells TD, Edmunds HM (1992) Algal blooms in high turbidity, a result of the conflicting consequences of turbulence on nutrient cycling in a shallow water estuary. Estuar Coast Shelf Sci 35:577-592

Fisher TR, Peele ER, Ammerman JW, Harding LW (1992) Nutrient limitation of phytoplankton in Chesapeake Bay. Mar Ecol Prog Ser 82:51-63

Franzs HG (1986) Effects of freshwater inflow on the distribution, composition and production of plankton in Dutch coastal waters. In: Skreslet E (ed) The role of freshwater outflow in coastal marine ecosystems. NATO ASI Ser G Ecol Sci 7. Springer-Verlag, Berlin, p 241-249

Grobbelaar JU (1990) Modelling algal productivity in large outdoor cultures and waste treatment systems. Biomass 21:279-314

Harwood JE, Kuhn AL (1970) A colorimetric method for ammonia in natural waters. Water Res 4:805-811

Hecky RE, Kilham P (1988) Nutrient limitation of phytoplankton in freshwater and marine environments: a review of recent evidence on the effects of enrichment. Limnol Oceanogr 33:796-822

Heip CHR, Goosen NK, Herman PMJ, Kromkamp J, Middleburg JJ, Soetaert K (1995) Production and consumption of biological particles in temperate tidal estuaries. Oceanogr Mar Biol Annu Rev 33:1-149

Humborg C, Ittekkot V, Coclasu A, Bodunges BV (1997) Effect of Danube River dam on Black Sea biogeochemistry and ecosystem structure. Nature 386:385-388

Irigoien X, Castel J (1997) Light limitation and distribution of chlorophyll pigments in a highly turbid estuary: the Gironde (SW France). Estuar Coast Shelf Sci 44: 507-517

Jensen A (1978) Chlorophyll and caretenoids. In: Heelebus JA, Craigie JS (eds) Handbook of phycological methods. Cambridge University Press, Cambridge
Joint IR, Pomeroy AJ (1981) Primary production in a turbid estuary. Estuar Coast Shelf Sci 7:185-195

Justic D, Rabalais, N, Turner RE, Dortch Q (1995) Changes in nutrient structure of river-dominated coastal waters: stoichiometric nutrient balance and its consequences. Estuar Coast Shelf Sci 40:339-356

Kinney EH, Roman CT (1998) Response of primary producers to nutrient enrichment in a shallow estuary. Mar Ecol Prog Ser 163:89-98

Kocum E, Nedwell DB, Underwood GJC (2002) Regulation of phytoplankton primary production along a hypernutrified estuary. Mar Ecol Prog Ser 231:13-22

Krom MJD (1980) Spectrophotometric determination of ammonia: a study of modified Berthelot reaction using salicyclate and dichloroisocyanurate. Analyst (Lond) 105: 305-317

Kromkamp J, Peene J (1995) Possibility of net phytoplankton primary production in the turbid Schelde estuary. Mar Ecol Prog Ser 121:249-259

Lawrence W, Harding LW Jr (1994) Long-term trends in the distribution of phytoplankton in Chesapeake Bay: roles of light, nutrients and stream flow. Mar Ecol Prog Ser 104: $267-267$

MacIsaac JJ, Dugdale RC (1972) Interactions of light and inorganic nitrogen in controlling nitrogen uptake in the sea. Deep-Sea Res 19:209-232

Malone TC, Conley DJ, Fisher TR, Glibert PM, Harding LW, Sellner KG (1996) Scales of nutrient-limited phytoplankton productivity in Chesapeake Bay. Estuaries 19: 371-385

Marker AFH, Collett GD (1997) Spatial and temporal characteristics of algae in the river Great Ouse. I. Phytoplankton. Regul Rivers Res Manag 13:219-233

Nielsen GE, Bresta AM (1984) Guidelines for the measurement of phytoplankton production. Baltic Marine Biologists, Uppsala

Nixon SW (1995) Coastal marine eutrophication: a definition, social causes and future concerns. Ophelia 41:199-210

Ogilvie B, Nedwell DB, Harrison RM, Robinson A, Sage A (1997) High nitrate, muddy estuaries as nitrogen sinks: the nitrogen budget of the River Colne Estuary (United Kingdom). Mar Ecol Prog Ser 150:217-228

Parsons TR, Maita Y, Lalli CM (1984) A manual of chemical and biological methods for seawater. Perganon, Oxford

Pennock JR (1985) Chlorophyll distribution in the Delaware Estuary: regulation by light-limitation. Estuar Coast Shelf Sci 21:711-725

Pennock JR, Sharp JH (1986) Phytoplankton production in the Delawere Estuary: temporal and spatial variability. Mar Ecol Prog Ser 34:143-155

Pennock JR, Sharp JH (1994) Temporal alteration between light- and nutrient-limitation of phytoplankton production in a coastal plain estuary. Mar Ecol Prog Ser 111:275-288

Platt T, Gallegos CL, Harrison WG (1980) Photoinhibition of photosynthesis in natural assemblages of marine phytoplankton. J Mar Res 38:687-701

Platt T, Sathyendranath, Ravindran P (1990) Primary production by phytoplankton: analytical solutions for daily rates per unit area of water surface. Proc R Soc Lond Ser B Biol Sci 241:101-111

Rendell AR, Horrobin TM, Jickells TD, Edmunds HM, Brown J, Malcolm SJ (1997) Nutrient cycling in the Great Ouse Estuary and its impact on nutrient fluxes to the Wash, England. Estuar Coast Shelf Sci 45:653-668

Robinson AD (1996) The Colne Estuary as a source of $\mathrm{N}_{2} \mathrm{O}$ and $\mathrm{NO}_{\mathrm{x}}$ gases to the atmosphere. $\mathrm{PhD}$ thesis, University of Essex, Colchester 
Sage AS (1995) Removal of nitrate from estuarine water and its reduction in the bottom sediments. PhD thesis, University of Essex, Colchester

Soetart KS, Herman PMJ, Kromkamp J (1994) Living in the twilight: estimating phytoplankton growth in the Westerschelde Estuary (The Netherlands) by means of an eco-system model (MOSES). J Plankton Res 16: $1277-1301$

Underwood GJC, Kromkamp J (1999) Primary production by

Editorial responsibility: Otto Kinne (Editor),

Oldendorf/Luhe, Germany phytoplankton and microphytobenthos in estuaries. Adv Ecol Res 29:93-153

van Spaendonk JCM, Kromkamp JC, de Visscher PRM (1993) Primary production of phytoplankton in a turbid coastal plain estuary, the Westerschelde (The Netherlands). Neth J Sea Res 31:267-279

Wofsy SC (1983) A simple model to predict extinction coefficients and phytoplankton biomass in eutrophic waters. Limnol Oceanogr 28(6):1144-1155

Submitted: January 11, 1999; Accepted: September 20, 2001 Proofs received from author(s): March 18, 2002 